\title{
WHY STUDY ERROR?
}

\section{Irawansyah}

State Islamic University of Raden Intan Lampung, Indonesia

(irawansyah@radenintan.ac.id)

\section{ABSTRACT}

There are many students still doing errors or mistakes in learning English as a foreign language (EFL) in Indonesia. Therefore, it is very important to study error. The error itself has long been an interest among foreign language researchers. The main task of error is how to describe a learning which occurs by examining students' output. It consists of correct and incorrect utterances. In this case, there are two approaches to learning students' errors, namely error analysis (EA) and contrastive analysis (CA). This paper only explains how error analysis is important in the teaching-learning process. It has many advantages when it is learned. EA has been classified into four types: linguistics category taxonomy, surface strategy taxonomy, comparative taxonomy, and communicative effect taxonomy. This study found error as an important tool for teachers and students to observe students' learning process and learning strategies.

Key Words: error analysis; error; mistakes; teaching-learning process

\section{ABSTRAK}

Ada masih banyak siswa yang melakukan error atau mistake dalam pembelajaran bahasa Inggris sebagai bahasa asing (EFL) di Indonesia. Oleh karena itu, hal ini sangat penting untuk mempelajari error. Error itu sendiri sudah lama dipelajari oleh peneliti-peneliti bahasa asing. Fungsi utama dari error itu sendiri adalah bagaimana mendeskripsikan pembelajaran yang terjadi dengan memeriksa hasil siswa. Hal ini terdiri dari ujaran yang benar dan salah. Dalam hal ini, ada dua pendekatan dalam mempelajari kesalahan siswa, yaitu analisis error (EA) dan analisis kontrastif (CA). Makalah ini hanya untuk menjelaskan bagaimana error analisis yang mempunyai banyak pengaruh dalam proses pembelajaran. Error analysis telah dikelompokkan menjadi empat jenis, yaitu kategori linguistik, kategori permukaan, kategori komparatif, dan kategori komunikatif. Temuan penelitian ini menyampaikan bahwa error sebagai sebuah alat yang penting bagi guru dan siswa untuk mengamati proses belajar dan strategi pembelajaran siswa.

Kata Kunci: analisis kesalahan, error; mistakes; proses belajar mengajar

How to Cite: Irawansyah (2017). Why Study Error?. IJEE (Indonesian Journal of English Education), 4(2), 120-129. doi:10.15408/ijee.v4i2.5972 


\section{INTRODUCTION}

It cannot be denied that many students often make errors or mistakes in the use of English as a foreign language (EFL) in Indonesia. Making errors are inevitable in a teachinglearning process. Many kinds of errors occur when students learn a foreign language. It is supported by Dulay et al. (1982) who stated that people cannot learn a language without first systematically commit errors.

Furthermore, James (1998) added that an error arises "only when there was no intention to commit one"(p.77). Many experts have discussed the understanding of error itself, for example, Richards (1971;1974), Dulay et al. (1982), James (1989;1998), Norrish (1983), and Ellis (1995). The results of their research were used in the second and foreign language teaching and learning.

\section{DESCRIPTION OF ERROR}

The error is something that is done through an awareness where the doer of the error him or herself knows where the error lies. Many experts conveyed the definition about the word of "error and mistake". Dulay et al. (1982) stated that errors are the flawed side of learner speech and writing. In addition, Brown (1980) also stated about error and mistake. The error is a noticeable deviation from the adult grammar or a native speaker reflecting the interlanguage competence of the learners, while the mistake is a performance error that is either a random guess or "slip", in that it a failure to utilize a known system correctly.

Meanwhile, Fauziati (2009) stated that errors are systematics, consistent deviance which is characteristics of the learner's linguistics system at a given stage of learning, and mistakes are deviation due to performance factors such as memory limitation, fatigue, and emotional strain.

\section{ERROR ANALYSIS}

Fauziati (2009) stated that error analysis as an approach to the study of SLA in which its primary focus is on learner errors and the evidence of how learner errors can provide an understanding of the underlying processes of second language learning or second language acquisition. Brown (1980) also mentioned the fact that learners' errors can be observed, analyzed, and classified to reveal something of the system operating within the learner, led to the surge of the study of learner's error, called 'error analysis'". 
There are two functions of error analysis : (1) to investigate the language learning process, and (2) to show whether it is necessary or not for the teacher to give the remedial teaching. Error analysis is described in four taxonomies, namely surface strategy, linguistics category, comparative, and communicative effect taxonomy.

\section{Surface strategy taxonomy}

The surface strategy taxonomy is classified based on the way surface structures that will be altered, such as omitting necessary items, adding unnecessary ones, misforming, misordering item (Dulay et al., 1982). In addition, James (1998) argued this taxonomy as target modification taxonomy which is classified based on the ways in which the learner's erroneous version is different from the presumed target version.

Analyzing error from this perspective has much promise for the researcher to concern with identifying cognitive processes that underlie the student's reconstruction of the new language. It also makes us aware that learner's errors result from their active ways of using the interim principles to produce the target language (Dulay et al., 1982). Under this taxonomy, errors consist of four types: omission, addition, misformation, and misordering (James, 1998). 1) The omission is one of the error types characterized by the absence of an item that must appear in a well-formed utterance, for example, his name George. It this sentence, the student omitted verb auxiliary such as is. It should be his name is George; 2) The addition is a type of error characterized by the presence of an item. It is the opposite of omission errors. It usually occurs when the students are often too faithful to use certain rules which result in errors. For example, The sparrows are flying. Here is the addition of morpheme " $s$ " with the sparrow that is not needed. The correct sentence is The sparrow is flying. At least, there are three types of addition errors, namely double marking, regularization, and simple addition; 3) Misformation is the use of the wrong form of a structure or morpheme. In misformation error, the student supplies an item although it is still incorrect, for example. He is licking himself. It should be He is licking himself. There are three categories of misformation error, in this case, namely regularization, archi-forms, and alternating forms. 4) Misordering is characterized by the incorrect placement of a morpheme or group of morphemes in an utterance. It occurs when towards to first and second language learning in constructions that have already been acquired, such as I do 
not know what is daddy doing. The correct sentence is I do not know what daddy is doing.

\section{Linguistics Category}

It classifies errors according to either or both the language component or the particular linguistics constituent the error effects. Language components include phonology (pronunciation), syntax and morphology (grammar), semantics and lexicon (meaning and vocabulary), and discourse (style). While constituents include the elements that comprise each language component (Dulay et al., 1982)

\section{Comparative Taxonomy}

This classification is based on the comparison between the structure of second language errors and certain other types of construction. If we use comparative taxonomy to classify the errors of an Indonesian student learning English, we might compare the structure of the learners' errors to that of errors reported for acquiring English as a first language. These comparisons have yielded two major error categories within this taxonomy: developmental errors and interlanguage errors (Dulay et al., 1982).

\section{Communicative Effect Taxonomy}

This type is based on "the perspective of their effect on the listener or reader". It deals much with distinguishing between errors that seem to cause miscommunication and those that do not. (Dulay et al., 1982). This research has shown that errors reflect the overall organization of the sentence usually do not hinder communication (Fauziati, 2009).

\section{SOURCE OF ERROR}

There are many sources of error itself. In general, the source of error consists of two parts, namely interlingual and intralingual transfer. Brown (1980) classified the source of errors into four categories. First, interlingual transfer, that is the negative influence of the mother tongue of the learner. Second, intralingual transfer, that is the negative transfer of items within the target language. Third, the context of learning, which overlaps both types of transfer, for example, the classroom with its teacher and its materials in the case of school learning or the social situation in the case of untutored second language learning.

Fourth, communication strategies. It is obvious that communication strategy is the conscious employment of verbal mechanisms for communicating 
an idea when linguistics forms are not available to the learner for some reasons. In addition, the communication strategies have five parts: (1) Avoidance is a common communication strategy that can be broken down into several subcategories, and thus distinguished from other types of strategies. The most common type of avoidance strategy is " syntactic or lexical avoidance' within a semantic category. When a learner, for example, cannot say "I lost my way" he/she might avoid the use of way and says "I lost my road" instead. "Phonological avoidance is also common, as in the case of a learner of English who finds initial /I/ difficult to pronounce and wants to say "he is a liar" may choose to say "he does not speak the truth".

(2) Prefabricated patterns which to memorize certain stock phrase or sentences without understanding the components of the phrases or sentences. "Tourist survival" language is full of prefabricated patterns, most of which can be found in pocket bilingual "phrase" books which list hundreds of stock sentences for various occasions. The examples of these prefabricated patterns are "how much does it cost?", "where is the toilet?",I do not speak English" and "I do not understand you". (3) Cognitive and personality style. One's own personal style of thinking can be a source of error, highlighting the idiosyncratic nature of many learners' errors.

A reflective and conservative style results in very careful, yet hesitant production of speech with perhaps fewer errors but errors indicative of the conscious application of rules. Such a person might also commit errors of over formality. A person with high selfesteem may be willing to risk more errors, in the interest of communication, because he does not feel as threatened by committing errors with a person with a low self-esteem. In answer to "how did you get here?" a person may be heard to say, "I drove my bicycle" while another might say, "I pedaled my bicycle" in an attempt to be precise. Language errors can thus conceivably be traced to sources in certain personal or cognitive idiosyncrasies.

(4) Appeal to authority. The learner may directly ask a native speaker (the authority) if he gets stuck by saying for example, "how do you say?' or he might guess and then ask for verification from the native speaker of the correctness of the attempt. He might also choose to look for a word or structure up in a bilingual dictionary. (5) Language Switch. Finally, when all other strategies fail to produce a meaningful utterance, a learner may switch to the so-called language switch. 
That is, he may simply use his native language whether the hearer understands that native language or not. Usually, just a word or two are slipped in, in the hope that learner will get the gist of what is being communicated.

Furthermore, Norrish (1983) classified causes of error into three types: 1) Carelessness. Carelessness is often closely related to the lack of motivation. Many teachers admit that it is not always the student's faults if he loses interest, perhaps the materials and/-or style of presentation does not suit him; 2) First language. Learning a language (mother tongue or foreign language) is a matter of habit formation. When someone tries to learn new habits, the old ones will interfere with the new ones. This cause of the error is called first language interference; 3) Translation. Translation is one of the causes of error. This happens because a student translates his first language sentence or idiomatic expression into the target language word for word. This is probably the most common cause of the error.

According to Richards (1971), there are four categories of causes of errors, namely: 1) Overgeneralization. It generally involves the creation of one deviant structure, for example, "he can sings". In that example, learners over- generalizes that are the simple present tense, " $s$ " ending is required by third person singular. The learners fail to realize that " $s$ " ending is not required anymore when a sentence in the simple present tense is introduced by an auxiliary verb; 2) Incomplete application of rules. This may occur when the learner has to respond immediately to questions made by the teacher and also appear when learners fail to apply the rules completely due to the stimulus sentence. An example of an incomplete application of rules can be seen in the question forms, for example:

\begin{tabular}{ll}
\hline Teacher's Questions & $\begin{array}{l}\text { Student's } \\
\text { Responses }\end{array}$ \\
\hline How much does it & It cost five dollar \\
cost? & \\
What does he have & $\begin{array}{l}\text { He have to do } \\
\text { write the address }\end{array}$ \\
to do? & $\begin{array}{l}\text { She tell him to } \\
\text { huarry does she tell }\end{array}$ \\
him?
\end{tabular}

As the above sample illustrates, when a question is used to elicit sentences, the answer often has to be corrected by the teacher to counteract the influence of this question. It means that the use of question may also be unrelated to the skills. It is meant to establish as a means of eliciting questions through a transform exercise; 3) False concepts hypothesized. False concepts hypothesized is due to the poor gradation of teaching items, for example, "one day it was happened" and 
"he is speaks English". The form 'was', may be interpreted as the marker of interference the past tense, and the " $i s$ " may be understood to be the corresponding marker of the present tense. 4) Ignorance of rule restriction. Closely related to the generalization of the deviant structure is the failure to observe the restriction of existing structures, that is, the application of rules to the context where they do not apply. For example, "Dion is the most tallest among his friends". The example is the type of generalization and transfer since the learner is making use of a previously acquired rule on a new situation.

\section{PROCEDURES FOR ERROR}

\section{ANALYSIS}

The set of procedures for conducting error analysis was originally proposed by Corder (1978). The procedure basically consists of three major stages, namely recognition, description, and explanation of errors. Furthermore, according to Sridhar (1980), there are some stages in error analysis: (1) collection of data; (2) identification of errors; (3) classification into error types; (4) statement of relative frequency of error types; (5) identification of the areas of difficulties in the target language; (6) therapy or remedial lesson; (7) analysis of the source of error.

\section{THE IMPLICATION OF THE ERROR ANALYSIS}

Fauziati (2009) stated that error analysis has a function as an analytical tool for understanding better the learners' problems in learning the second language. Furthermore, one of the purposes of conducting error analysis is to identify the principles for an effective error correction. It means that it can help the teachers devise remedial lessons which help learners better learn the target language so that they can develop their interlanguage system. Corder (1967) stated that the usefulness of error analysis in three respects: to the researcher, to the language teacher, and to the learner himself/herself.

In learning errors, there are many benefits because it can identify strategies which learners use in language teaching. In addition, it is able to identify the causes of the learners' errors. Furthermore, it can help obtain information on common difficulties in language learning as an aid to teaching or in development of teaching materials(Richards, et.al.,1992). According to Erdogen (2005), the implication of error analysis to language teaching can be viewed from 
two aspects, namely language teachers, and syllabus designers.

\section{The implication for Foreign Language Teachers}

In some cases, there are many advantages when the teachers find error analysis. Corder (1987) stated that errors tell teachers how far learners have progressed towards the goal and what remains for them to learn. In addition, following the learners' progress, teachers can carry out their studies in accordance with what learners need to know and what part of the teaching strategy to chance or reconstruct. In this case, errors are a means of feedback for the teacher reflecting how effective he/she is in his/her teaching style and what changes he/she has to make to get higher performance from his/her students. Furthermore, errors indicate the teacher the points that need further attention. Additionally, errors show the way to be treated when their sources are identified correctly (Erdogen, 2005).

\section{The implication for Syllabus Designers}

In teaching learning process, a syllabus design is needed, especially in English courses because it is a very important component. There are many factors that should be considered to decide on what to teach to what level and age group. At this point, errors are significant data for syllabus designers as they show what items are important to be included or which items need to be recycled in the syllabus (Erdogen,2005). Keshavarz argued that an error-based analysis can give reliable results upon which remedial materials can be constructed.

In other words, an analysis of second language learners' error can help identify learners' linguistics difficulties and needs at a particular stage of language learning. It is essential for a syllabus to provide with the needs for learning appropriately, and errors are important evidence for that.

In addition, errors are also useful in assessing teaching materials, for example, in Chiang's view (1981) of the English composition course of the NTNU English department. The high frequencies of errors found in the compositions may indicate the insufficiency for the students to master the written component of the language.

Furthermore, Chiang's research also found that there are other pedagogical implications of the error analysis. The first is the usefulness and need of remedial programs. When the result of error analysis shows huge frequencies of errors, remedial 
programs of some kind are necessary. The second one. The development of error-based teaching materials and syllabuses for use in the composition class. Patterns of errors can be built up into a classified inventory of errors together with the most revealing examples in the corpus. The third is the implication for individualized instruction.

As one of the general trends in TESL and in education, in general, is towards individualization of instruction, the error-analysis practice is perhaps one of the most effective means of understanding the individualities of the learners. The fourth is understanding the strategies of the learners. Understanding students' learning strategies, the teacher will be in a better position to teach. The fifth is understanding the strategies of the learner. Understanding students' learning strategies, the teacher will be in a better position to teach. The sixth is implications for teaching methodology. As observed, many of the composition classes are based on the sole philosophy that "the more the students write, the better they write". After the error analysis, this needs to be slightly modified into "The more a student is a guided to write, the better he or she writes".
Khansir (2012) stated that error analysis has several implications for the handling of learner's errors in the classroom as follows: 1) Devising remedial measures; 2) Preparing a sequence of target language items in the classroom and textbook within the difficulties items coming after the easier ones.

Richards et al. (1992) mentioned the study of errors are used in order to: (1) identify strategies which learners use in language teaching, (2) identify the causes of learner's errors, and (3) obtain information on common difficulties in language learning as an aid to teaching or in development of teaching materials.

Based on the explanation that has been mentioned previously, the research question is formulated into: "Is it important to learn error?".

The objective of this research is to explain how error analysis is important in the teaching-learning process. Many advantages will be gotten when error analysis is learned.

The significance of this research is to provide new insights towards error analysis theories which have many advantages in the learning process in Indonesia. 


\section{CONCLUSION AND SUGGESTION}

The error has a very important role for teachers and students. This paper helps introduce about error analysis itself and how it contributes to teaching-learning process, especially in English language teaching process as the foreign language in Indonesia. Referring to the explanation above, it can be concluded that error analysis identifies the strategies that language learners use. Furthermore, it can determine the common difficulties in learning, and also help the teachers develop materials for remedial teaching. If the errors occur, the teacher should understand the source of error itself. The reason is, through the understanding source of error, the teacher is able to provide an appropriate remedy that will resolve the students' problems and allow the teacher to discover the relevant rules.

Thus, an important clue for the teacher to decide on the sort of treatment is the source of error. Harmer (1998) suggested that there are three steps that should be followed by the teacher when errors occur. The teacher first listens to the students, then identifies the problem, and puts it right in the most efficient way. In conclusion, the inevitable existence of errors has led researchers to learn on them and find out the natural steps for language learning. Thus, findings of error analysis function as a facilitator in language teaching in many ways only if the teacher is aware of them and able to make the appropriate use of them in the teaching process

\section{REFERENCES}

Brown, H. D. (1980). Principles of language learning and teaching. New Jersey: Prentice Hall, Inc.

Corder, S. P. (1967). The significance of learners' errors. IRAL - International Review of Applied Linguistics, 5, 161170.

Corder, S.P. (1987). Error analysis and interlanguage. Oxford: Oxford University Press.

Chiang, T.(1981)."Error analysis: A study of errors made in written English by Chinese Learners". Unpublished M.A. Thesis, NTNU.

Dulay et al. (1982). Language two. New York: Oxford University Press.

Fauziati, E. (2009). Reading on Applied Linguistics: A handbook for language teacher and teacher-researcher. Surakarta: Era Pustaka Utama.

Harmer, J. (1998). How to teach English. Essex: Longman.

James, K. (1998). Errors in language learning and use: Exploring error analysis. London: Longman.

Richards, J. C. (1971). A non-contrastive approach to Error Analysis. Journal of ELT. 25, 204-219.

Richards et al. (1992). Dictionary of language teaching and applied linguistics. Essex: Longman. 